\title{
Performance and Propaganda in Spanish America during the War of the Spanish Succession
}

\author{
Aaron Alejandro Olivas
}

In September 1708, the royal officials of Caracas submitted to the Spanish crown a zealous handwritten account of their nine-day festivities commemorating the birth of Don Luis, the prince of Asturias. Held a year earlier, the celebrations honouring the new-born heir to the throne included public acclamations of Philip v as true king of Spain, followed by illuminations, military and religious processions, and a banquet hosted by French slave traders. Despite the hardships endured throughout the Caribbean during the War of the Spanish Succession, the spectacles in Venezuela also facilitated the collection of ten thousand pesos in silver for the urgencies of the Bourbons' European and North African campaigns. More importantly for local elites, however, the account served as an opportunity to discredit 'idle voices' circulating from Havana that the caraqueños had recently proclaimed Archduke Charles as their sovereign with the aide of Dutch forces in Curaçao-allies of the Habsburgs. Such an incident had notoriously occurred in Venezuela in 1702 and had required immediate counteraction. Six years later, the royal officials needed the account of their celebrations for the prince of Asturias to reassure Philip v of his 'reacclamation' by the populace as well as their full commitment to the Bourbon dynasty's objectives in the war: victory over the enemy Dutch and English, the defence of a united Spanish monarchy, and the preservation of the Catholic faith. ${ }^{1}$

Spectacle accounts such as these have provided scholars with rich source material for understanding the experiences of the War of the Spanish Succession as a global conflict - above all, the uncertainty and disorder the war provoked in the Iberian Atlantic World. The crown's particular demands for wartime spectacles and their execution by viceregal officials were supposed to emphasize the coherence of a single monarchy working together in a time of crisis to preserve Bourbon rule over the Spanish empire. Nonetheless, while Spanish colonial accounts do convey a sense of shared imperial struggle, they

1 Cabildo of Caracas to Philip v, Caracas, 3 September 1708, Archivo General de Indias (AGI), Santo Domingo, 717 .

(C) KONINKLIJKE BRILL NV, LEIDEN, 2015 | DOI 10.1163/9789004304789_013 
also expose a heightened sense of discord and rivalry between social groups, cities, and even competing European empires as a result of the dynastic transition. These public performances do in fact emphasize the larger connections Spanish-American subjects had to the succession crisis as well as their role in its final conclusion and victory. Among other things, these acclamations of Philip v demonstrate the importance of public rituals in legitimizing political authority, reinforcing unity within the Hispanic monarchy, and mediating local concerns in late colonial Spanish America.

Legitimizing the new dynasty's rule over Spanish America-the world's most important silver-producing region - was an urgent concern for Philip v and his closest advisors. Although it was unclear whether or not armed conflict would erupt in Europe, by November 1700 ministers of state in Madrid were convinced that the succession and subsequent 'Union of the Two Crowns' between Spain and France would prompt the English and the Dutch to instigate a war in the Americas. These fears were well-founded, as evident in the outbreak of violence in the Caribbean and Pacific Rim beginning in the summer of 1702 and lasting through the end of 1712. As colonial correspondence and wartime maps suggest, the Habsburgs' allies responded to the dynastic quarrel in Europe with a commercial war targeting the silver fleets and principal Spanish-American trade routes. ${ }^{2}$ Throughout this period, Anglo-Dutch agents used both aggressive measures (such as commerce raiding) and peaceful means (such as pamphleteering and smuggling) in their attempts to persuade Spanish colonial subjects to recognize Habsburg sovereignty as a challenge to Philip v's alliance with the French. ${ }^{3}$

2 Pierre Mortier, Téâtre de la guerre en Amerique telle qu'elle est à present possedée par les Espagnols, Anglois, François, et Hollandois \&c. (Amsterdam: P. Mortier, 1703). For example, Mortier's map highlights important Spanish colonial trade routes targeted by the Dutch and English navies in the Caribbean. By the end of the seventeenth century, the viceroyalties of New Spain and Peru had become the world's most lucrative markets for African slaves and European manufactured goods (above all, luxury textiles) — demands stimulated by the mining economies of Northern Mexico and the Andes.

3 David Marley's Wars of the Americas: a Chronology of Armed Conflict in the Western Hemisphere (Santa Barbara, CA: ABC-CLIO, 2008) offers the broadest overview of the military history of Spanish America during the War of the Spanish Succession. Charles Arnade and W. Stitt Robinson have written about the earliest skirmishs in Spanish Florida and the northern borderlands. J. Ignacio Rubio Mañé deals with confrontations between novohispanic militias and Jamaican privateers and logwood cutters in the Yucatan Peninsula in El Virreinato, Vol. III: Expansión y defensa (Mexico City: Universidad Autónoma de México, 1983). Carla Rahn Phillips, Charles Boxer, and Eduardo Brazão have written about major naval battles such as the English admiral Charles Wager's assalt on the Peruvian silver fleet at 


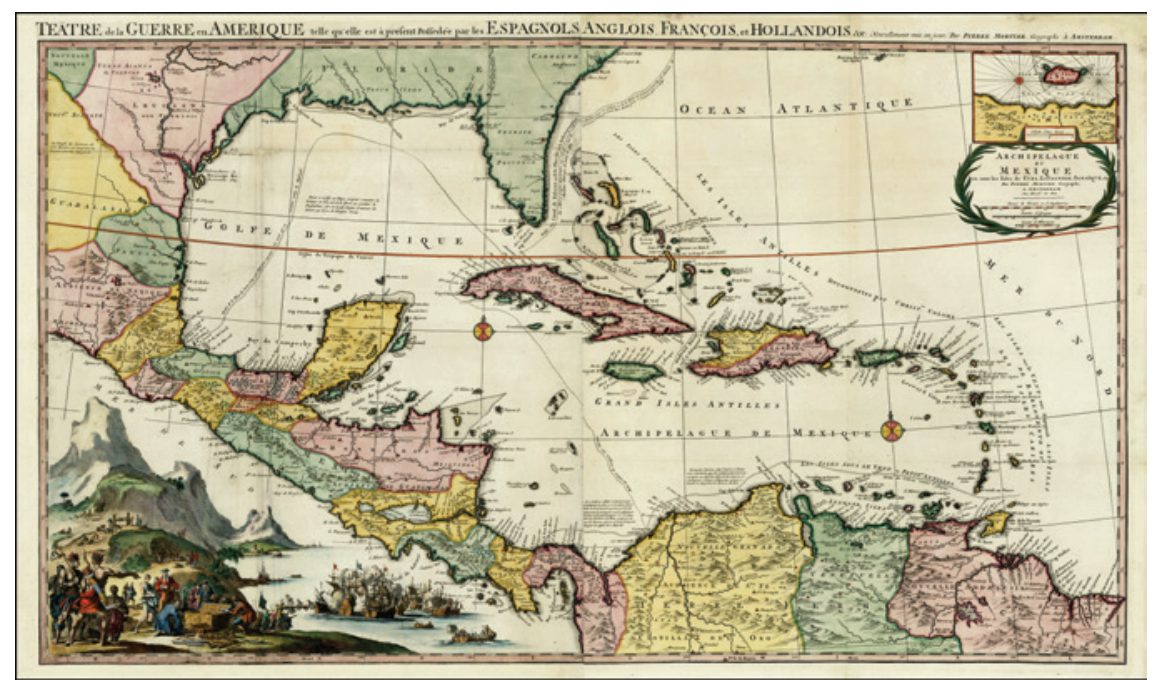

FIGURE 11.1 Téâtre de la guerre en Amerique telle qu'elle est à present possedée par les Espagnols, Anglois, François, et Hollandois \&c. (Amsterdam: P. Mortier, 1703). BIBLIOTECA NACIONAL DE ESPAÑA

From the start of Philip v's rule, the Spanish crown counted on a deliberate program of spectacles to safeguard Spanish-American loyalties from such enemy assaults. ${ }^{4}$ The official proclamation regarding the succession—-delayed due to a disagreement between the king and the Council of the Indies over colonial defence-first arrived in Veracruz on March 3, 1701 with orders for the admiral of the silver fleet and all royal officials to honour a clause in Carlos II's testament to immediately display of the pendón (royal standard) in recognition of Bourbon succession even before proceeding with the exequies for the late king. A clear break with standard ceremonial protocol, the urgency of this initial spectacle was meant to ensure instant legitimization of the political transition in the face of potential resistance among the colonial populace-whether inspired by Anglo-Dutch propaganda or any lingering sympathies for the

Caragena de Indias (1708) and the French corsair René Duguay-Trouin's victory at the battle of Rio de Janeiro (1711).

4 David González Cruz, 'Propaganda y estrategias de legitimación de la sucesión en los dominios de la Monarquía Hispánica (1700-1714),' in La sucesión de la Monarquía Hispánica, 1665-1725: biografías relevantes y procesos complejos, ed. José Manuel Bernardo Ares (Madrid: Sílex, 2009), 201-203. 
Habsburgs. ${ }^{5}$ Again, the crown's concerns were rather justified. Public knowledge of disloyalty among certain elites in Spain spread to Spanish America at the same time as the succession proclamation and continued to be a popular source of gossip throughout the war. ${ }^{6}$ Although these cases did not immediately inspire colonial disloyalty, later ones-such as uprisings in Cremona and Naples and the defection of the Admiral of Castile to the Habsburg causeinfluenced sedition and conspiracies in places such as Caracas (1702), Panama City (1704), and Mexico City (1707). ${ }^{7}$

The use of public ceremonies as inoculation against colonial Austriacism may have had its limits, yet it was still highly successful for conveying propaganda for the new dynasty. Such ceremonies, of course, were a common part of the everyday lives of Spanish-American subjects, much like in other parts of the Spanish Empire. The most expected of these festivals, known as fiestas de tabla, were official holidays approved by the crown and based on the liturgical calendar, with the exception of the años del rey (king's birthday), and the años de la reina, (queen's birthday). Even these were marked by Catholic overtones but also constant references to Bourbon military progresses. The Spanish crown exerted control over public festivals to the extent that communities were legally obligated to celebrate the fiestas de tabla and any other holidays demanded by the monarch. To ensure the celebration of the approved festivals, fiestas de tabla were required by law to be marked on tables or charts and displayed publically, both in religious spaces—such cathedrals and

5 Víctor Mínguez Cornelles, 'Imperio y muerte: las exequias de Carlos in y el fin de la dinastía a ambas orillas del Atlántico,' in Arte, poder e identidad en Iberoamérica: de los virreinatos a la construction nacional, ed. Inmaculada Rodríquez Moy (Castellón de la Plana: Universitat Jaume I, 2008), 33-43; María José del Río Barredo, 'Los rituales públicos de Madrid en el cambio de dinastía (1700-1710), in Philip v y su tiempo, ed. Eliseo Serrano (Zaragoza: Institución Fernando el Católico, 2004), II: 736-737. The decree sent to Spanish America was dated a mere three days after the public acclamation of Philip v in Madrid spectacles. It reached Lima by 27 April 1701. The matter of raising the pendón had even been a concern in Madrid, where the regency council accelerated the staging of Philip v's acclamation ceremony to 24 November 1700 - within forty-eight hours of Louis XIV's acceptance of the will and five months before the new king made his entry into the capital - in order to discourage any Habsburg pretensions.

6 Antonio de Robles, Diario de Sucesos Notables (1665-1703), vol. 3, ed. Antonio Castro Leal (Mexico City: Editorial Porrúa, S.A., 1946), 145; 157-159.

7 AGI, Escribanía 69oA; AGI, México 661; François-Amboise Daubenton de Villebois to the comte de Pontchartrain, Madrid, 22 June 1704, ANF, Marine, B7 232, fol. 52-53. 
churches—and secular spaces—-such as the halls of municipal councils and royal courtrooms. ${ }^{8}$

Royal officials in the viceroyalties would be notified of additional holidays by the arrival of proclamations from the Spanish court. These were required to be announced in public squares by pregoneros - town criers usually of Indigenous or African descent. Ecclesiastical and secular officials were required by law to participate in these celebrations as well as plan many of the festivities, otherwise face penalties. For example, during the acclamation ceremony for Philip v, there was a 10 peso fine imposed on any royal official who neglected to participate in illuminations along the parade route of the pendón, the symbolic representation of the absentee monarch. Heavier fines could be expected at the end of an official's term in office if he was denounced to the crown in his juicio de residencia, or trial of residence, for lack of participation in spectacles. ${ }^{9}$

Although the crown was insistent about the celebration of specific holidays and events, it seldom stipulated how these public festivals should be celebrated, leaving communities at liberty to mark these occasions 'in the manner most accustomed'-a common phrase in the decrees. Therefore, royal officials, municipal magistrates, and local clergy could determine for themselves the number of days and the types of festivities for each holiday. As such, their planning and execution became a central duty in the careers of colonial authorities - and one that could be used to advance them. ${ }^{10}$

Spanish colonial subjects witnessed a prodigious series of festivals during the War of the Spanish Succession, as Philip v demanded the major events of his succession and the war to be celebrated throughout the empire. Each of these celebrations reminded royal officials and the general populace alike of the Union of the Two Crowns-Spain's dynastic alliance with France that was also political, economic, military, and religious in nature. These public spectacles can be grouped together in three categories: celebrations of milestones in the lives of the members of the Bourbon dynasty, celebrations of

8 Alejandro Cañeque, The King's Living Image: the Culture and Politics of Viceregal Power in Colonial Mexico (New York: Routledge, 2004), 132-142.

9 Miguel Ángel Marín, 'El sonido de una ciudad pequeña en tiempos de Philip v', in Philip V y su tiempo, ed. Eliseo Serrano (Zaragoza: Institución Fernando el Católico, 2004), II: 18-19.

10 Mínguez, 'Imperio y muerte,' $17-51$; Frances L. Ramos, 'Succession and Death: Royal Ceremonies in Colonial Puebla,' The Americas 6o:2 (2003): 185-215. Mínguez and Ramos have noted the importance of local variation and ingenuity in Bourbon spectacles in both colonial Mexico City and Puebla de los Ángeles. 
Bourbon military victories, and the celebration of a new war-related religious holiday. ${ }^{11}$

Of the celebrations pertaining to the royal family, the first and most immediate events commemorated Philip v's arrival in Madrid, his acclamation as king of Spain, and the king's marriage to Maria Luisa of Savoy — all of which occurred between 1701 and 1702. These were followed between 1707 and 1709 by celebrations for the pregnancy of the queen, which required acts of thanksgiving for her good health, festivities commemorating the eventual birth of don Luis, prince of Asturias, and-at age two-the prince's jura as successor to the throne. Celebrations for the birth of the king's second son, the Infante Ferdinand, followed in 1713. Similar festivities dedicated to royal births had not been celebrated in the Spanish Empire in over forty years, as Carlos II produced no heirs during his reign. There were also important spectacles commemorating royal deaths, which took place between 1711-1715. These not only commemorated the 1714 passing of Queen Maria Luisa of Savoy but also deaths among the Bourbons of France, such as Philip v's father, the Dauphin, who died 1711, and the king's brothers, the Duke of Burgundy and the Duke of Berry, who died in 1711 and 1712 respectively. Later the death of Louis XIV in 1715 was observed throughout the Spanish colonies as well-commemorated in Mexico City with a catafalque in the cathedral. ${ }^{12}$

Celebrations for Bourbon military victories focused on the peninsular campaigns of the War of the Spanish Succession, although news of the Italian and Northern European campaigns circulated widely. The most important military celebrations revolved around the recapture of Madrid from the Allied army in 1706 and 1710, the battle of Almansa in 1707, the 1709 victories along the Portuguese border, and the successive victories at Zaragoza, Brihuega, and Villaviciosa between 1710-1711. Likewise, in 1711, Philip v proclaimed a new religious holiday, known as the Celebration of the Holy Sacrament, in the wake of the Allied retreat from Castile. This event was observed in December, on the Sunday after the Immaculate Conception, as an annual votive fiesta commemorating the sacrileges committed by the Habsburgs' allies, particularly Anglo-Dutch pillaging of Castilian churches and their desecration of the Eucharist at many of these religious sites. According to a Franciscan sermon

\footnotetext{
11 Del Río, 'Los rituales públicos de Madrid,' 752. These colonial spectacles followed patterns set by court ceremonial in Madrid, which were equally propagandistic in nature.

12 Victor Mínguez, 'La imagen de Luis XIV en sus exequias novohispanas: la "Flor Francesa" y el 'Espeso de Príncipes,"' in Tiempos de Latinoamérica, ed. M. Chust, V. Mínguez, and V. Ortells (Castellón de la Plana: Biblioteca de la Universitat Jaume I), 85-112.
} 
from the celebrations in Puebla, Philip v's reverence for the Immaculate Conception and the Eucharist would unquestionably assure his victory in the war. $^{13}$

We get a sense of just how excessive this sequence of dynastic holidays, military commemorations, and religious ceremonies could be in a 1710 letter from the Audiencia of Guadalajara to the viceroy of New Spain. In the letter, the president of the audiencia noted that work on the city's aqueduct had been set back a good eight years due to the length of the wartime festivities, their expense, and the resulting incapacity of the city's laborers due to continuous drunkenness - the ban on mescal having been lifted at the beginning of Philip v's reign for such special occasions. ${ }^{14}$ Nonetheless, Philip v's heavy demand for spectacles in Spanish America can be considered part of a larger Bourbon strategy to winning a global war. The governments of Philip V and Louis XIV expected the wealth of Spanish America to finance the war in Europe, given the wide circulation of silver and gold specie in the Spanish colonies. ${ }^{15}$ Hence the growing multitude of public celebrations during the war served as fundraising opportunities to tap into that wealth through the request of donativos, or voluntary donations to the crown. Along with the benefits of Spanish American trade, donativos acted as vital sources of revenue for the Bourbons, and by-and-large contributed to prolonging the war. The crown's requests for such donativos in New Spain and Peru always coincided with public holidays: for example, the first donativo declared in 1701 for the relief of Ceuta and Oran in Spanish North Africa, two general ones for the urgencies of the war in 1703 and 1705, three for the Catalan campaigns in 1707, 1713, and 1714, several requests in the 1710 s for endeavours in Naples, and the last in 1715 for the reconquest of Mallorca. ${ }^{16}$

Although donations were supposed to be voluntary, in reality they were expected, and the ability to collect them could make or break the career of a

13 'A los virreyes del Perú y Nueva España, gobernadores, arzobispos, obispos, y ciudades de ambos reinos para que en todas las iglesias de sus territorios se celebre una fiesta votiva anual en el día que se señala a Nuestro Señor Sacramentado en desagravio de los ultrajes que le fueron hechos por los enemigos de la religión,' Corella, 19 June 1711, AG I, Indiferente General 432, fol. 230v-233r.

14 Toribio Rodríguez de Solís to the Duke of Alburquerque, Guadalajara, 30 September 1710, Archivo General de la Nación Mexicana, Reales Cédulas Originales 34, fol. 99r-106v.

15 François-Amboise Daubenton de Villebois to the comte de Pontchartrain, Madrid, 26 October 1703, Archives Nationales de France (ANF), Marine, $B^{7}$ 229, fol. 221r-226r.

16 The file AGI Indiferente General 431 (book 45) gives testimony to the crown's incessant call for colonial donativos throughout the war. 
royal official. For example, the Duke of Alburquerque, viceroy of New Spain, was rewarded with the toison de oro and a longer term in office for successfully raising one million pesos during the 1707 celebrations for the birth of the prince of Asturias. By contrast, the marquis of Castelldosrius, viceroy of Peru, did not appear as useful to the crown in this regard, which in part led to his disgrace by $1708 .{ }^{17}$

Public spectacles were also geared towards controlling information about the progresses of the war, as the crown hoped to prevent the possibility of wavering loyalties by publicizing through celebrations the successes of Bourbon troops and Philip v's fulfilment of his duties as king - above all, to protect the foral privileges of his subjects and produce heirs. Both the courts of Madrid and Versailles were quite concerned about conveying an impression across the Atlantic that the Bourbons were winning the war in order to combat pro-Habsburg propaganda campaigns led by the English and the Dutch. Particularly after 1704, the English secretaries of the Southern DepartmentHedges and Sunderland - and also the directors of the Dutch West India Company encouraged colonial governors in Jamaica and Curaçao to take a non-violent approach to the war by using smugglers to disperse engravings of the Archduke and Spanish-language pamphlets, gazettes, and amnesty decrees throughout Spanish America. The objective was to implant doubts about Bourbon sovereignty, raise anxieties about the intentions of the French, and promise arms and naval support should Spanish colonial subjects revolt in the name of the Archduke. Naturally, the campaigns were also geared towards boosting Anglo-Dutch trade, with the assumption that once Archduke Charles was firmly in place on the throne and recognized as king of Spain, England and the Netherlands would be granted the Spanish colonial trade privileges enjoyed by the French under Philip v. ${ }^{18}$ Similar propaganda campaigns were

17 'Memorandum,' Madrid, 14 March 1707, Archives du Ministère des Affaires Étrangères de France (AE), Correspondance Politique, Espagne, 167, fol. 73r-74v; Michel-Jean Amelot de Gournay to Louis XIV, Madrid, March 17, 1707, AE, Correspondance Politique, Espagne, 167, fol. 77r-8or; Louis XIV to Michel-Jean Amelot de Gournay, Fontainebleau, 30 July 1708, AE, Correspondance Politique, Espagne, 181, fol. 115r-116v; Michel-Jean Amelot de Gournay to Louis XIV, Madrid, 13 August 1708, AE, Correspondance Politique, Espagne, 181, fol. 203r-208r.

18 For example, see Sir Charles Hedges to Thomas Handasyde, Saint James's, 4 May 1704, Calendar of State Papers Colonial, America and West Indies, Volume 22: 1704-1705, ed. Cecil Headlam (London: Her Majesty's Stationery Office, 1916), 111-123; the Earl of Sunderland to Thomas Handasyde, Windsor, 19 July 1708, in Calendar of State Papers Colonial, America and West Indies, Volume 24:1708-1709, ed. Cecil Headlam (London: Her Majesty's Stationery Office, 1922), 37 . 
highly effective in Catalonia and Valencia, and did in fact contribute to an outcropping of cases of disloyalty and sedition among elites in Spanish America and the Philippines, which spanned the entire duration of the war. The most common crimes were those of lese majesté and sedition, either by word of mouth or by circulating enemy pamphlets and engravings. However, there were also cases of actual interest in inciting revolts in the name of the Archduke with Anglo-Dutch aide. ${ }^{19}$

To conclude, it is crucial to note the importance of local uses of wartime spectacles in proving the loyalty of colonial elites and reinforcing the bonds of patronage with Bourbon Spain and even France, as paranoia of political disintegration rocked the empire. This particular usage of ceremony was apparent not long after the acclamation of Philip v in the America. For example, the commander of the fort of San Juan de Ulúa in Veracruz, who in a letter to Philip v relished in the fact that he was the first in Mexico to display the new dynasty's banner, considered the gesture worthy of a pension or noble privilege. Likewise, the feverish endeavours of the indigenous lords of Tlaxcala to stage a royal acclamation ceremony in their city before celebrations in Mexico City allude to the potential advantages of patronage to be garnered during the succession crisis. By publishing descriptions of their triumphal arches and loas from the event, the Tlaxcalteca assured Philip $\mathrm{v}$ of their support of his succession and thus justified their request that the king restore the tax exemptions long bestowed on them by Emperor Charles v for their assistance of Cortés's army in the conquest of Mexico. ${ }^{20}$ Similarly, the Count of la Moncolva, viceroy of Peru, staged the lavish opera La púrpura de la rosa on the king's birthday in 1701 as a response to popular rumours in Lima that he was sympathetic to the Habsburgs. The libretto was based on a play by Calderón de la Barca that was originally used to celebrate the marriage of Louis XIV to Infanta Maria Teresa and again to celebrate the marriage of Carlos II to the Duchess of Orleans,

19 For a broad overview of these cases, see Aaron Alejandro Olivas, 'Loyalty and Disloyalty to the Bourbon Dynasty in Spanish America and the Philippines During the War of the Spanish Succession (1700-1715)' (dissertation, the University of California, Los Angeles, 2013). Also, Analola Borges's monograph La Casa de Austria en Venezuela durante la Guerra de Sucesión española (Salzburg / Tenerife: [s.n.], 1963) and Luis Navarro García's conspiración en México durante el gobierno del Virrey Alburquerque (Valladolid: CasaMuseo de Colón, Seminario Americanista de la Universidad de Valladolid, 1982) deal with particular cases in Caracas and Mexico City. 
so the viceroy's choice of the piece was supposed to subtly suggest to the king his support of the Union of the Two Crowns. ${ }^{21}$

As demonstrated by the zeal of the royal officials of Caracas in celebrating the birth of the prince of Asturias, such ceremonies were instrumental in conveying to Philip v Spanish colonial dedication to his cause in the war as well as strengthening trans-imperial bonds with the France crown. Accounts such as this emphasize Spanish royal officials' devotion to the Union of the Two Crowns and the inclusion of French military and slave company personnel in public celebrations, evoking a sense of friendship and cooperation between the two nations in the face of Anglo-Dutch opposition. Therefore, public displays of Bourbon support were also supposed to reassure patronage bonds and loyalty to the French court.

21 José A. Rodríguez Garrido, 'El teatro cortesano en la Lima colonial: recepción y practicas esénicas,' Histórica 32:1 (2008): 115-143. 